\title{
Odonata of Sungai Bebar, Pahang, Malaysia, with four species recorded for the first time from mainland Asia
}

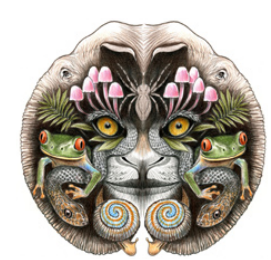

\author{
Rory A. Dow ${ }^{1}$, Yong Foo $\mathrm{Ng}^{2} \&$ Chee Yen Choong ${ }^{3}$ \\ ${ }^{1}$ NCB Naturalis, P.O. Box 9517, 2300 RA Leiden, The Netherlands \\ ${ }^{2,3}$ Centre for Insect Systematics, Faculty of Sciences and Technology, Universiti Kebangsaan Malaysia, 43600 Bangi, Selangor D.E. \\ Malaysia \\ Email: ${ }^{1}$ rory.dow230@yahoo.co.uk (corresponding author), ${ }^{2}$ ng_yf@ukm.my, ${ }^{3}$ cychoong@ukm.my
}

Date of publication (online): 26 March 2012 Date of publication (print): 26 March 2012 ISSN 0974-7907 (online) | 0974-7893 (print)

Editor: Albert Orr

Manuscript details:

Ms \# 03041

Received 19 December 2011

Final received 06 January 2012

Finally accepted 13 February 2012

Citation: Dow, R.A., Y.F. Ng \& C.Y. Choong (2012). Odonata of Sungai Bebar, Pahang, Malaysia, with four species recorded for the first time from mainland Asia. Journal of Threatened Taxa 4(3): 2417-2426.

Copyright: (c) Rory A. Dow, Yong Foo Ng \& Chee Yen Choong 2012. Creative Commons Attribution 3.0Unported License. JoTT allows unrestricted use of this article in any medium for non-profit purposes, reproduction and distribution by providing adequate credit to the authors and the source of publication.

Author Details: See end of this article.

Author Contribution: RAD identification of, and information on, the Odonata collected, collection of specimens. YFN information on the area sampled, and on peat swamp forest in Peninsular Malaysia; organization of the sampling trip. CYC identification of, and information on, the Odonata collected, collection of specimens, photography.

Acknowledgements: The authors wish to thank the Pahang Forestry Department for granting permission for sampling of Odonata in the Sungai Bebar, Runchang, Pahang. This study was funded by research grants UKM-GUP-ASPL-07-04-048 and UKM-ST06-FRGS0184-2010. We also wish to thank Professor Yong Hoi Sen for his company and stimulating conversation during our fieldwork at Sungai Bebar, and Doctor Albert Orr for his continued support of our work. Thanks are also due to Mr Marcel Silvius for allowing us to report his photographic record of Tyriobapta laidlawi here.
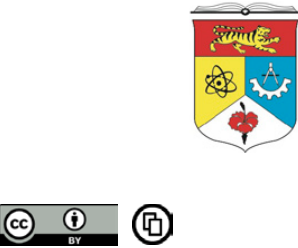

OPEN ACCESS | FREE DOWNLOAD
Abstract: Records are presented of Odonata collected in September 2009 from the Sungai Bebar and the surrounding area, in Pekan Forest Reserve, southeastern Pahang, Peninsular Malaysia. A total of 50 species from nine families were collected. Two of the species listed, Amphicnemis bebar and A. hoisen, were first discovered during this survey. Another four previously known species were recorded in mainland Asia for the first time: Elattoneura coomansi, Elattoneura longispina, Brachygonia ophelia and Tyriobapta laidlawi.

Keywords: Damselflies, dragonflies, Malaysia, new records, Odonata, Pahang, peat swamp forest, Pekan Forest Reserve, Sungai Bebar.

Bahasa Melayu Abstract: Rekod persampelan Odonata dari Sungai Bebar dan kawasan berhampiran Hutan Simpan Pekan, selatan Pahang, Semenanjung Malaysia dalam September 2009 dilaporkan. Sejumlah 50 spesies pepatung daripada sembilan famili telah disampel. Dua spesies baru telah diperihal daripada persampelan ini: Amphicnemis bebar dan A. hoisen. Empat spesies yang direkod adalah rekod baru kepada tanah besar Asia: Elattoneura coomansi, Elattoneura longispina, Brachygonia ophelia dan Tyriobapta laidlawi.

\section{INTRODUCTION}

In September 2009 Professor Yong Hoi Sen and the authors made a short Odonata sampling trip to Sungai Bebar in Pekan Forest Reserve. Sungai Bebar is situated in southeastern Pahang, Peninsular Malaysia (Fig. 1). Sungai Bebar flows southeastern through Pekan, Kedondong and Nenasi forest reserves before entering the South China Sea at Nenasi. Dow et al. (2010) incorrectly stated that the forest reserve where sampling took place was Nenasi FR. Much of Sungai Bebar is surrounded by disturbed peat swamp forest. Malaysia originally had an estimated 1.54 million hectares of peat swamp forest, but less than $20 \%$ was in Peninsular Malaysia (UNDP 2006). We do not have figures for how much peat swamp forest remains today, but it has been reduced to scattered, fragmentary remnants, mostly in Selangor, Pahang and Johor states; the largest such area is located in southeastern Pahang and consists of Pekan, Kedondong, Nenasi and Resak forest reserves.

Swamp forest in general, and peat swamp forest in particular, has been little surveyed for Odonata in Peninsular Malaysia. Norma-Rashid et al. (2001) reported on odonate surveys at Tasek Bera, a lake in Pahang with a large area of swamp forest around it, including peat swamp forest; however, most of the collecting reported in that publication appears to have been made on the lake and surrounding river channels; little sampling appears to have taken place inside the swamp forest. Hämäläinen (2000) 


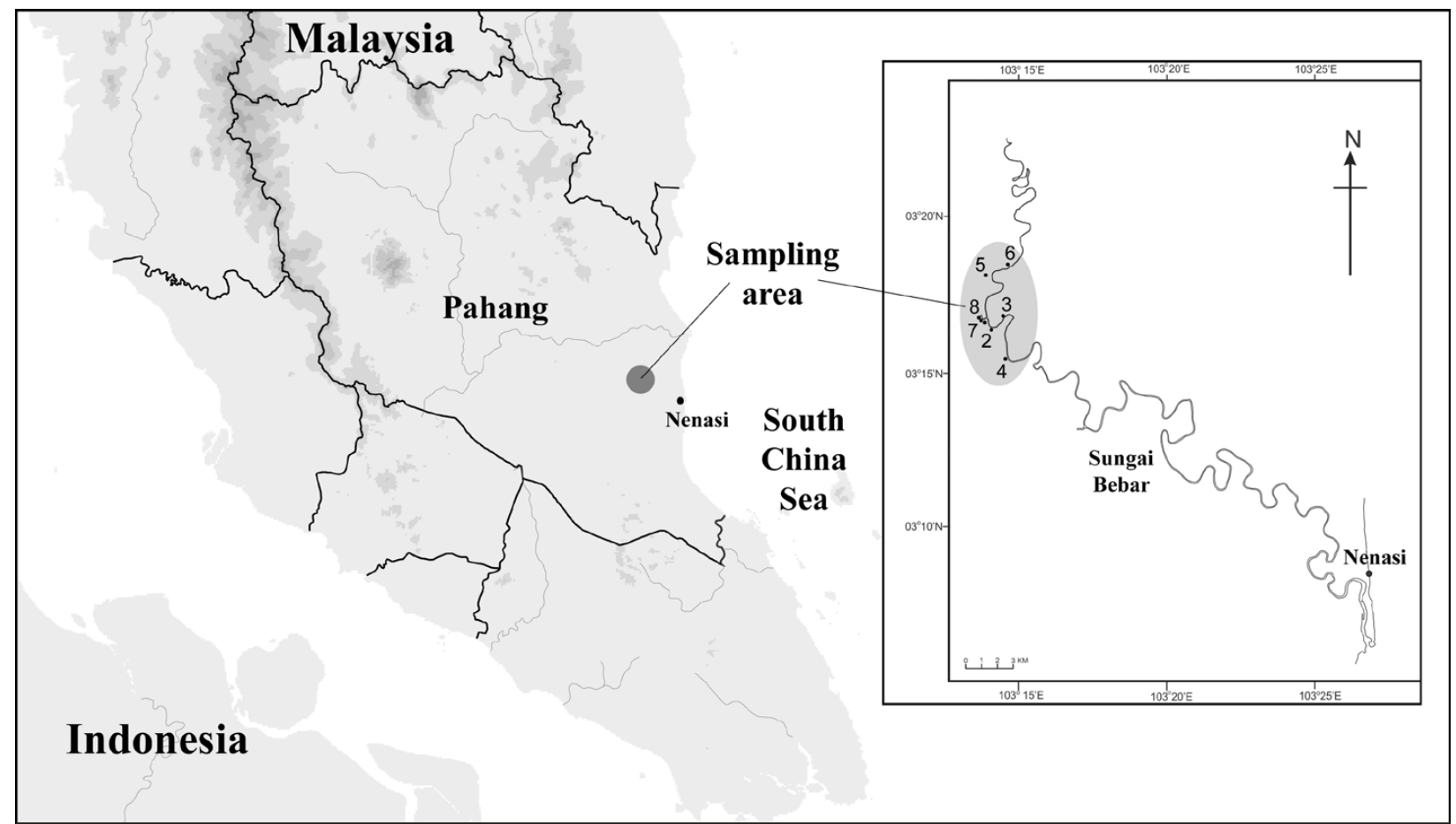

Figure 1. Sampling area in Peninsular Malaysia.

includes a number of records made in swamp forests of various types. In 2006, CYC collected odonates from swamp forests in Panti Forest Reserve, Johor (Choong 2009). Other records from swamp forest in Peninsular Malaysia are scattered amongst the odonatological literature of the last century.

In the present survey, six species not previously reported from Peninsular Malaysia were found. Two were of the coenagrionoid genus Amphicnemis and new to science; these species (A. bebar and A. hoisen) were described by Dow et al. (2010). The other four species, two members of the Protoneuridae (Elattoneura coomansi Lieftinck and E. longispina Lieftinck) and two from the Libellulidae (Brachygonia ophelia Ris and Tyriobapta laidlawi Ris), had not previously been recorded from mainland Asia but were known either from Borneo, or Borneo and the Indonesian Islands of Belitung and Bangka. Here we list all the species collected in the Sungai Bebar area, with details of specimens collected and notes on species of particular interest.

\section{MATERIALS AND METHODS}

\section{Study sites}

Sampling was carried out at the locations listed below (Fig. 1), from 20-24 September 2009:

(1) On the Sungai Bebar (Image 1) between locations 4 and 6.

(2) Margin of the Sungai Bebar with emergent vegetation, chiefly Pandanus, at the water margin and in disturbed scrub inland, $3^{0} 16.845^{\prime} \mathrm{N} \& 103^{0} 13.894^{\prime} \mathrm{E}$ and $3^{\circ} 16.604^{\prime} \mathrm{N} \& 103^{\circ} 14.446$ 'E.

(3) Tributary of the Sungai Bebar (Image 2) and surrounding highly disturbed swamp forest, $3^{0} 17.134^{\prime} \mathrm{N} \& 103^{0} 14.878^{\prime} \mathrm{E}$.

(4) Highly disturbed swamp forest at $3^{0} 15.650$ 'N \& $103^{\circ} 14.687^{\prime} \mathrm{E}$.

(5) Less disturbed swamp forest (Image 3) with stream, $3^{0} 18.696^{\prime} \mathrm{N} \& 103^{0} 14.120^{\prime} \mathrm{E}$.

(6) Highly disturbed swamp forest (Image 4) at $3^{0} 19.372^{\prime} \mathrm{N} \& 103^{0} 15.136^{\prime} \mathrm{E}$.

(7) Black water drains and a stream in a mosaic of highly disturbed forest and open meadow and road, $3^{0} 17.078^{\prime} \mathrm{N} \& 103^{0} 13.559^{\prime} \mathrm{E}$.

(8) A pond at the edge of degraded forest at $3^{0} 17.173^{\prime} \mathrm{N} \& 103^{0} 13.368^{\prime} \mathrm{E}$.

(9) Water filled wheel ruts near location 2. 


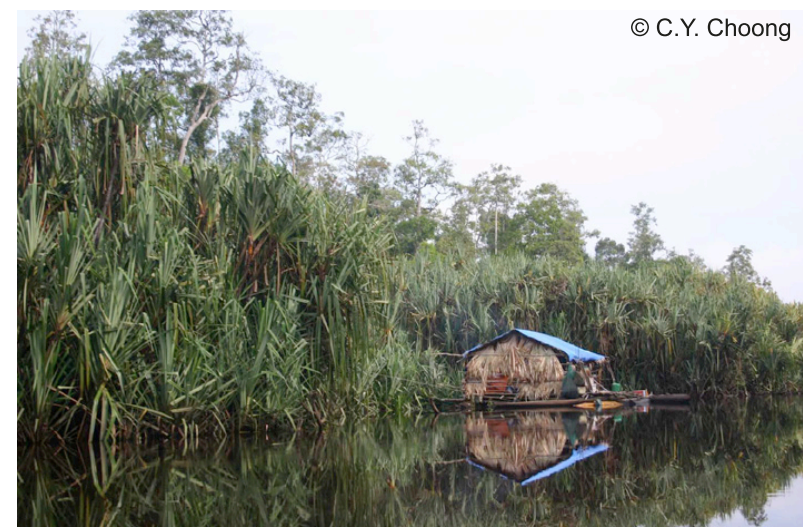

Image 1. The Sungai Bebar.

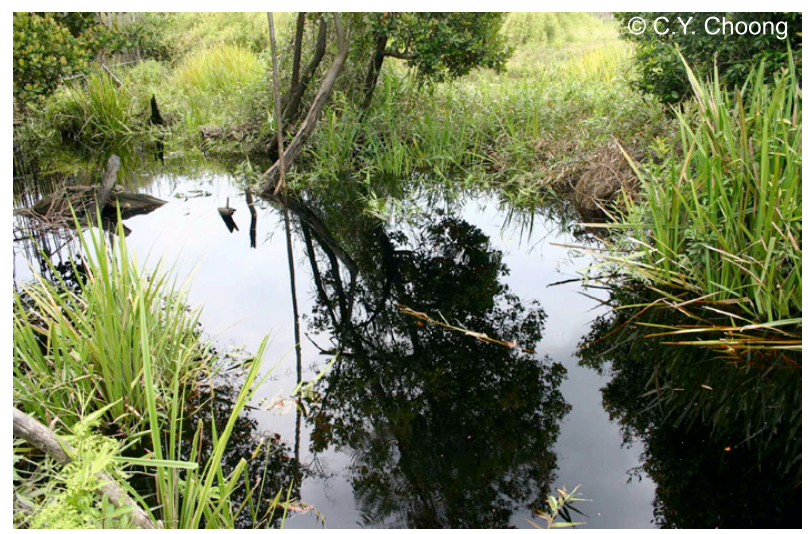

Image 2. Tributary to the Sungai Bebar (location 3).

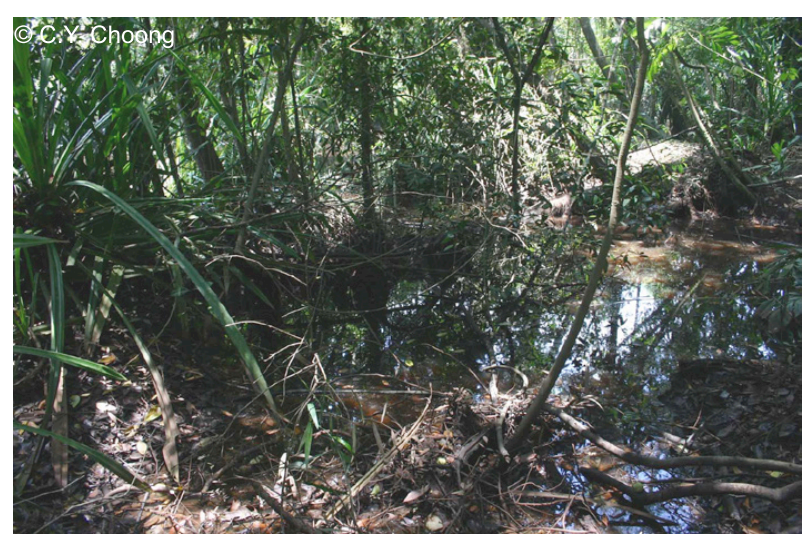

Image 3. Swamp forest in Pekan Forest Reserve (location 4).

\section{Sampling and identification}

Adult specimens were collected using handheld nets. Sampling on the Sungai Bebar was conducted from a boat. Specimens were preserved either by treatment with acetone, drying or immersion in ethanol. The family level taxonomy used below follows that in Orr (2005).

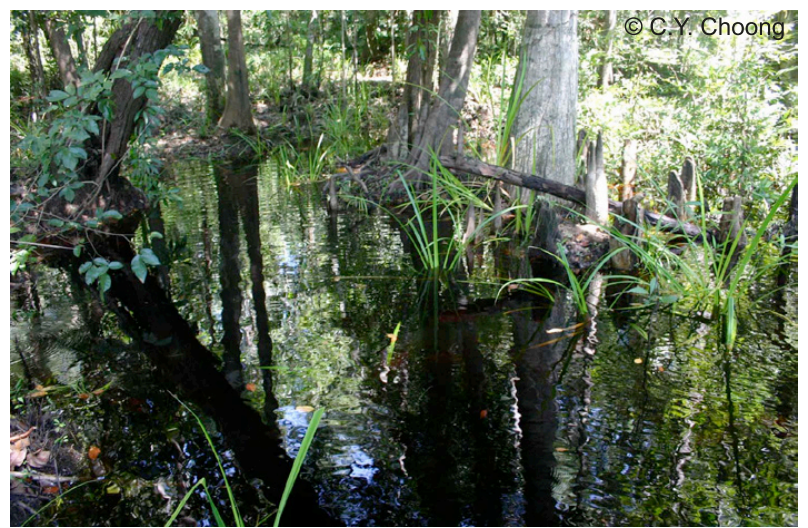

Image 4. Swamp forest in Pekan Forest Reserve (location 6).

The material collected is held in either the Centre for Insect Systematics at Universiti Kebangsaan Malaysia (UKM), the Netherlands Centre for Biodiversity Naturalis (RMNH), collection CYC or collection RAD. Material was identified to species using a stereomicroscope, with reference to relevant literature, and direct comparison with material, including type material, held in The Natural History Museum, London (BMNH) and RMNH.

\section{RESULTS}

A total of 218 individual Odonata specimens were collected, comprising 50 species in nine families. Species, locations and number of specimens collected at each location on a given date are listed below, together with notes on species of particular interest. For species of Amphicnemis, details of specimens collected at Sungai Bebar are given in Dow et al. (2010) and are not repeated here. The species recorded at each location sampled are summarised in Table 1.

\section{Zygoptera \\ Chlorocyphidae}

(i) Libellago hyalina Selys, 1859 - 2, 3:4 males, 2 females, RAD, 20.ix; 2 males, 1 female, CYC, 20.ix; 4:1 male, 1 female, RAD, 21.ix.

\section{Megapodagrionidae}

(i) Podolestes buwaldai Lieftinck, 1940 - There are few published records of this species, originally described from Sumatra (Lieftinck 1940). Hämäläinen (2000) made the first report for Peninsular Malaysia; 
Table 1. Species recorded at each sampling site.

\begin{tabular}{|c|c|c|c|c|c|c|c|c|c|}
\hline \multirow[b]{2}{*}{ Species } & \multicolumn{9}{|c|}{ Sampling Site } \\
\hline & 1 & 2 & 3 & 4 & 5 & 6 & 7 & 8 & 9 \\
\hline Agriocnemis femina & & & & & & $\mathrm{y}$ & & & \\
\hline Agriocnemis minima & & & & & & & & & $\mathrm{y}$ \\
\hline Agriocnemis nana & & & & & & $\mathrm{y}$ & & & \\
\hline Amphicnemis bebar & & & & & $\mathrm{y}$ & $\mathrm{y}$ & & & \\
\hline Amphicnemis gracilis & & & $\mathrm{y}$ & & & $\mathrm{y}$ & & & \\
\hline Amphicnemis hoisen & & & & & $\mathrm{y}$ & & & & \\
\hline Archibasis incisura & & $\mathrm{y}$ & & & & & & & \\
\hline Archibasis melanocyana & & & & & $\mathrm{y}$ & & & & \\
\hline Brachydiplax chalybea & & & & & & & $\mathrm{y}$ & $\mathrm{y}$ & \\
\hline Brachygonia oculata & & & & $\mathrm{y}$ & $\mathrm{y}$ & $\mathrm{y}$ & $\mathrm{y}$ & & \\
\hline Brachygonia ophelia & & & & & $\mathrm{y}$ & & & & \\
\hline Ceriagrion cerinorubellum & & & & & & & $\mathrm{y}$ & & \\
\hline Ceriagrion species & & & & & $\mathrm{y}$ & & & & \\
\hline Chalybeothemis fluviatilis & $\mathrm{y}$ & $\mathrm{y}$ & $\mathrm{y}$ & & & & & $\mathrm{y}$ & \\
\hline Copera ciliata & & & & & & & $\mathrm{y}$ & & \\
\hline Copera vittata & & & & & & $\mathrm{y}$ & & & \\
\hline Elattoneura aurantiaca & & $\mathrm{y}$ & & $\mathrm{y}$ & $\mathrm{y}$ & $\mathrm{y}$ & & & \\
\hline Elattoneura coomansi & & $\mathrm{y}$ & & & $\mathrm{y}$ & $\mathrm{y}$ & & & \\
\hline Elattoneura longispina & & & & & $\mathrm{y}$ & & & & \\
\hline Epophthalmia vittigera & $\mathrm{y}$ & & & & & & & & \\
\hline Gomphidia abbotti & $\mathrm{y}$ & & & & & & & & \\
\hline Ictinogomphus acutus & $\mathrm{y}$ & & & & & & & & \\
\hline Ictinogomphus decoratus & $\mathrm{y}$ & & & & & & & & \\
\hline Ischnura senegalensis & & & & & & & $\mathrm{y}$ & & \\
\hline Libellago hyalina & & $\mathrm{y}$ & $\mathrm{y}$ & $\mathrm{y}$ & & & & & \\
\hline Macrogomphus decemlineatus & $\mathrm{y}$ & & & & & & & & \\
\hline Macromia cincta & $\mathrm{y}$ & & & & & & $\mathrm{y}$ & & \\
\hline Nannophya pygmaea & & & & & & & $\mathrm{y}$ & & \\
\hline Nesoxenia lineata & & & & $\mathrm{y}$ & & & & & \\
\hline Neurothemis fluctuans & & & & & & & $\mathrm{y}$ & & \\
\hline Oligoaeschna species & & & & $\mathrm{y}$ & & & & & \\
\hline Onychothemis testacea & $\mathrm{y}$ & & & & & & & & \\
\hline Orchithemis pruinans & & & & $\mathrm{y}$ & $\mathrm{y}$ & & & & \\
\hline Orchithemis pulcherrima & & & $\mathrm{y}$ & & & & & & \\
\hline Orthetrum chrysis & & $\mathrm{y}$ & & & & & $\mathrm{y}$ & & \\
\hline Pantala flavescens & & $\mathrm{y}$ & & & & & & & \\
\hline Podolestes buwaldai & & & & & $\mathrm{y}$ & $\mathrm{y}$ & & & \\
\hline Pornothemis serrata & & & & $\mathrm{y}$ & $\mathrm{y}$ & & & & \\
\hline Potamarcha congener & & & & & & & & & $\mathrm{y}$ \\
\hline Prodasineura humeralis & & & & & $\mathrm{y}$ & & & & \\
\hline Pseudagrion rubriceps & $\mathrm{y}$ & & & & & & & & \\
\hline Pseudagrion williamsoni & $\mathrm{y}$ & $\mathrm{y}$ & & & & & & $\mathrm{y}$ & \\
\hline Rhyothemis aterrima & & $\mathrm{y}$ & & & & & & & \\
\hline Rhyothemis obsolescens & & $\mathrm{y}$ & & $\mathrm{y}$ & & & & & \\
\hline Rhyothemis phyllis & & $\mathrm{y}$ & & & & & & & \\
\hline Rhyothemis pygmaea & & & & & $\mathrm{y}$ & & & & \\
\hline Risiophlebia dohrni & & & $\mathrm{y}$ & & & & & & \\
\hline Tyriobapta laidlawi & & & & & $\mathrm{y}$ & & & & \\
\hline Urothemis signata insignata & & & & & & & $\mathrm{y}$ & & \\
\hline Zyxomma petiolatum & & & & $\mathrm{y}$ & & & & & \\
\hline Total number of species & 10 & 11 & 5 & 9 & 15 & 9 & 10 & 3 & 2 \\
\hline
\end{tabular}


Kalkman (2004) and Choong et al. (2008) also recorded it from Malaysia. At Sungai Bebar it was moderately common in the least disturbed swamp forest area sampled. 5:3 male, 2 female, RAD, 22.ix; 3 male, 2 female, RAD, 23.ix; 2 males, 2 females, CYC, 23.ix; 6:1 male, 1 female, RAD, 24.ix; 1 female, CYC, 24.ix.

\section{Protoneuridae}

(i) Elattoneura aurantiaca (Selys, 1886) - 2:5 male, 1 female, RAD, 20.ix; 1 male, 1 female (in tandem), CYC, 20.ix; 4:1 male, RAD, 21.ix; 5:3 male, RAD, 22.ix; 2 males, 1 female, RAD, 23.ix; 6:2 males, RAD, 23.ix.

(ii) Elattoneura coomansi Lieftinck, 1937 - This is the first record of this species from Peninsular Malaysia; it is otherwise known from Kalimantan and Bangka and Belitung islands (Lieftinck 1954). Most of the specimens collected were taken amongst Pandanus at the edge of Sungai Bebar 2:4 male, RAD, 20.ix; 5:1 male, RAD, 23.ix; 6:1 female, RAD, 24.ix.

(iii) Elattoneura longispina Lieftinck, 1937 This species has not been recorded from mainland Asia before; it was described from west Kalimantan and is also known from Sarawak (Dow \& Unggang 2010) and Belitung (Lieftinck 1954). One male was collected at Sungai Bebar. However, in 2006 CYC collected two tandem pairs of this species from Pondok Tanjung Forest Reserve, northern Perak, a small peat swamp forest; these specimens were misidentified as Elattoneura analis (Selys 1860) and the mistake was only discovered in early 2010. This species is expected to have wider distribution in Peninsular Malaysia and might also occur in southern Thailand. 5:1 male, CYC, 22.ix.

(iv) Prodasineura humeralis (Selys, 1860) - 5:1 male, CYC, 23.ix.

\section{Coenagrionidae}

(i) Agriocnemis femina (Brauer, 1868) - 6:1 female, RAD, 24.ix.

(ii) Agriocnemis minima (Selys, 1877) — 9:1 male, 2 females (1 pair in tandem), RAD, 21.ix; 1 male, CYC, 21.ix.

(iii) Agriocnemis nana (Laidlaw, 1914) - 7:1 male, 2 females, CYC, 20.ix.

(iv) Amphicnemis bebar Dow et al., 2010 - See Dow et al. (2010) for a discussion of this and the next two species. Locations 5 and 6 (Image 5).

(v) Amphicnemis gracilis Krüger, 1898 Locations 3 and 6.

(vi) Amphicnemis hoisen Dow et al., 2010 Location 5 (Image 6).

(vii) Archibasis incisura Lieftinck, 1949 — This is a rather local species, and its preferred habitat is probably streams and rivers in low $\mathrm{pH}$ swamp forest, for instance see Dow \& Unggang (2010). 2:2 male, RAD, 20.ix; 1 male, CYC, 23.ix.

(viii) Archibasis melanocyana (Selys, 1877) - 5:1 male, CYC, 23.ix; 1 male, CYC, 24.ix.

(ix) Ceriagrion cerinorubellum (Brauer, 1865) 7:1 male, RAD, 20.ix; 1 male, CYC, 20.ix.

(x) Ceriagrion species - A single female, identical in general appearance to C. cerinorubellum, collected in peat swamp forest. It differs from $C$. cerinorubellum, and all other species of Ceriagrion, in having the central part of the pronotal posterior lobe deeply and squarely excised; this does not appear to be the result of damage to the specimen, but the possibility that it is simply an abnormal individual of C. cerinorubellum cannot be ruled out unless further examples are collected. 5:1 female, RAD, 23.ix.

(xi) Ischnura senegalensis (Rambur, 1842) - 7:1 male, CYC, 20.ix.

(xii) Pseudagrion rubriceps Selys, $1876-1: 1$ male, RAD, 20.ix.

(xiii) Pseudagrion williamsoni Fraser, $1922-1: 1$ male, RAD, 20.ix; 2:2 males, CYC, 20.ix; 8:1 male, RAD, 21.ix.

\section{Platycnemididae}

(i) Copera ciliata (Selys, 1863) - 7:1 female, CYC, 20.ix.

(ii) Copera vittata (Selys, 1863) - 6:1 male, RAD, 24.ix.

\section{Anisoptera \\ Gomphidae}

(i) Gomphidia abbotti Williamson, 1907 - 1:1 male, RAD, 22.ix.

(ii) Ictinogomphus acutus (Laidlaw, 1914) - 1:1 male, RAD, 21.ix; 1 male, RAD, 22.ix; 2 males, CYC, 22.ix.

(iii) Ictinogomphus decoratus melaenops (Selys, 1858) - 1:1 male, RAD, 22.ix.

(iv) Macrogomphus decemlineatus (Selys, 1878) 

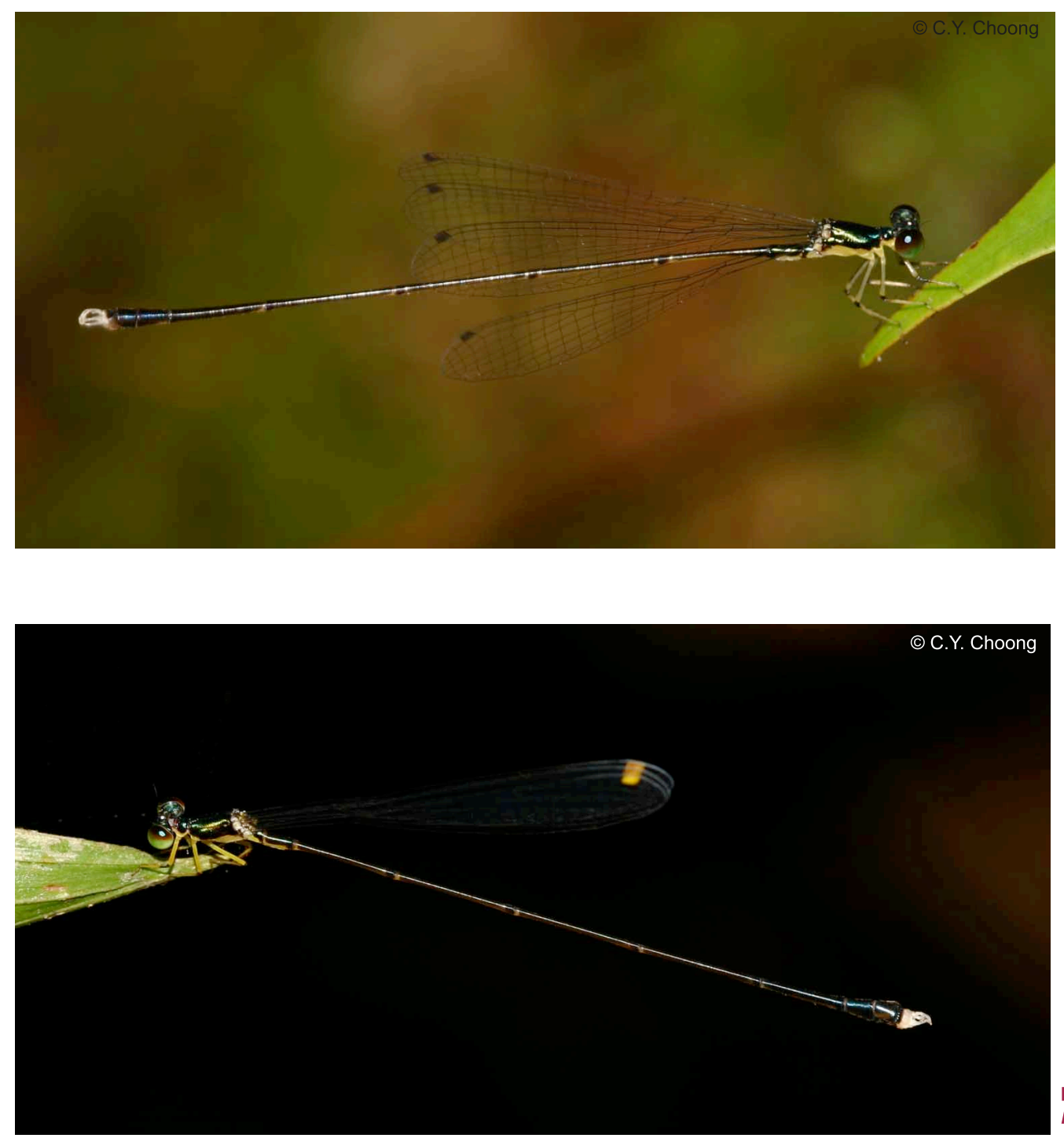

Image 6. Amphicnemis hoisen male.

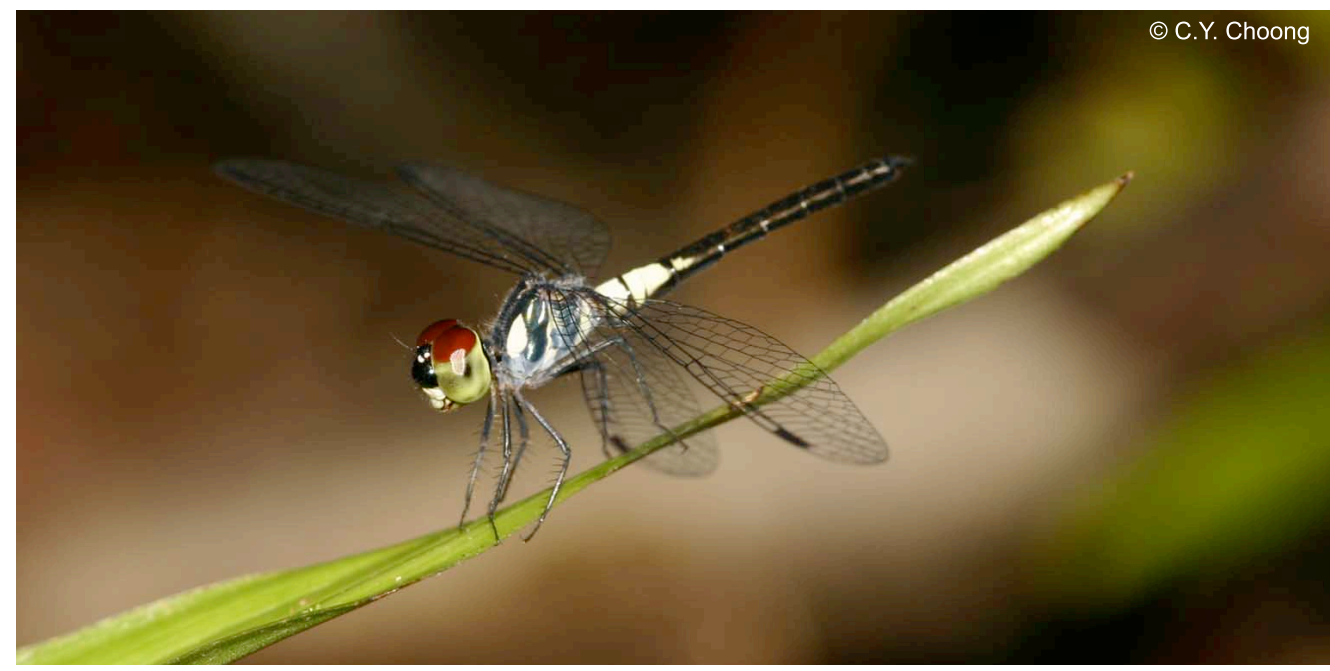



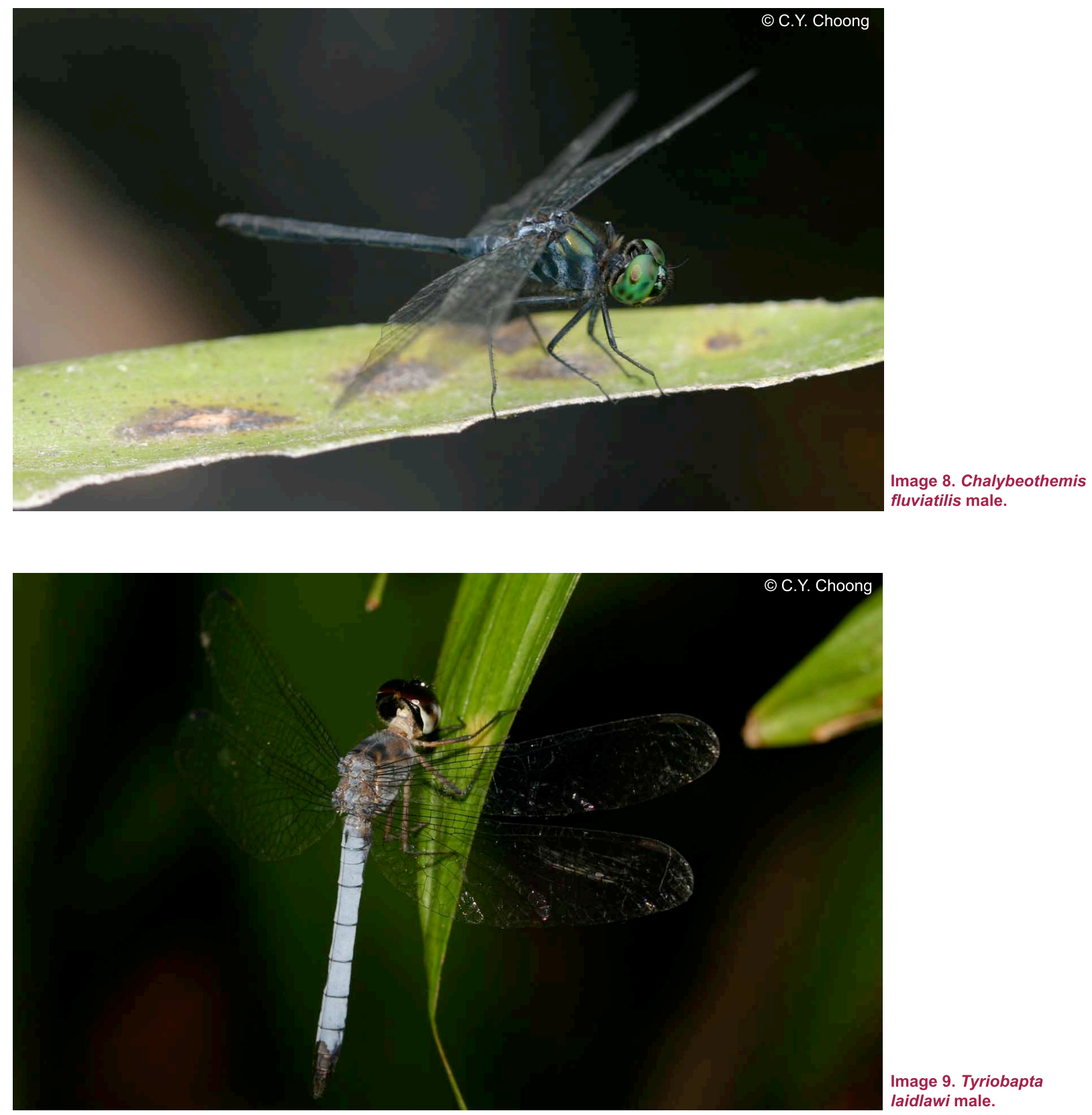

- 1:1 male, RAD, 21.ix; 1 male, CYC, 24.ix.

\section{Aeshnidae}

(i) Oligoaeschna species - It has not proved possible to identify the single female collected reliably to species. 4:1 female, RAD, 21.ix.

\section{Corduliidae}

(i) Epophthalmia vittigera (Rambur, 1842) - 1:1 male, CYC, 21.ix.

(ii) Macromia cincta Rambur, 1842 - 1:1 male, RAD, 22.ix; 1 male, CYC, 21.ix; 1 male, CYC, 22.ix;
7:1 male, RAD, 20.ix.

\section{Libellulidae}

(i) Brachydiplax chalybea Brauer, 1868 - 7:1 male, CYC, 20.ix; 1 male, CYC, 22.ix; 8:1 male, RAD, 21.ix.

(ii) Brachygonia oculata (Brauer, 1878) - 4:1 male, RAD, 21.ix; 5:1 female, CYC, 23.ix; 6:1 male, RAD, 24.ix; 7:1 male (in forest), RAD, 21.ix; 2 males (in forest), CYC, 21.ix.

(iii) Brachygonia ophelia Ris, 1910 - This very local swamp forest species has not been recorded 
from Peninsular Malaysia until now; it is otherwise only known from scattered locations in Borneo (e.g. Lieftinck 1954, Orr $2001 \&$ 2003). Image 7. 5:2 males, RAD, 22.ix; 1 male, 1 female, RAD, 23.ix; 2 males, CYC, 23.ix.

(iv) Chalybeothemis fluviatilis Lieftinck, 1933 This species is known from scattered locations across Borneo, Sumatra, Belitung, Singapore and Peninsular Malaysia and southern Thailand (Dow et al. 2007). It often appears to prefer low $\mathrm{pH}$ habitats, but occurs on MacRitchie Reservoir in Singapore (Tang et al. 2010). It was common on parts of Sungai Bebar during the sampling period. Image 8. 1:1 male, RAD, 21.ix; 1 male, RAD, 22.ix; 2:1 male, RAD, 20.ix; 3:2 males (on the tributary); RAD, 20.ix; 2 males (on the tributary), CYC, 20.ix; 8:1 male, RAD, 21.ix.

(v) Nannophya pygmaea Rambur, 1842 - 7:1 male, RAD, 20.ix; 1 male, CYC, 21.ix.

(vi) Nesoxenia lineata (Selys, 1879) - 4:2 males, CYC, 21.ix.

(vii) Neurothemis fluctuans (Fabricius, 1793) 7:1 male, RAD, 20.ix; 1 male, CYC, 20.ix.

(viii) Onychothemis testacea Laidlaw, $1902-1: 1$ male, CYC, 21.ix.

(ix) Orchithemis pruinans (Selys, 1878) - 4:5 males, RAD, 21.ix; 5:1 female, RAD, 22.ix; 1 male, RAD, 23.ix; 2 males, CYC, 21.ix.

(x) Orchithemis pulcherrima Brauer, 1878 - 3:1 male, CYC, 20.ix.

(xi) Orthetrum chrysis (Selys, 1891) - 2:1 male, RAD, 20.ix; 7:1 male, CYC, 20.ix.

(xii) Pantala flavescens (Fabricius, 1798) - 2:1 female, RAD, 21.ix; 1 male, CYC, 20.ix; 1 male, CYC, 21.ix.

(xiii) Pornothemis serrata Krüger, $1902-4: 2$ males, RAD, 21.ix; 2 males, 1 female, CYC, 21.ix; 5:1 male, RAD, 22.ix.

(xiv) Potamarcha congener (Rambur, 1842) - 9:1 male, RAD, 20.ix; 1 male, CYC, 20.ix.

(xv) Rhyothemis aterrima Selys, $1891-2: 1$ male, RAD, 20.ix; 1 male, CYC, 21.ix.

(xvi) Rhyothemis obsolescens Kirby, $1889-2: 1$ male, RAD, 20.ix; 1 male, CYC, 20.ix; 4: 1 male, RAD, 21.ix.

(xvii) Rhyothemis phyllis (Sulzer, 1776) - 2:1 female, RAD, 20.ix; 1 female, CYC, 20.ix.

(xviii) Rhyothemis pygmaea (Brauer, 1867) - 5:1 male, RAD, 22.ix; 1 male, CYC, 23.ix; 1 male, CYC, 24.ix.

(xix) Risiophlebia dohrni (Krüger, 1902) - 3:1 male, RAD, 20.ix.

(xx) Tyriobapta laidlawi Ris, 1919 - This species, otherwise known from Borneo, has not been recorded from Peninsular Malaysia before. It appears to be most common in low $\mathrm{pH}$ swamp forest. A convincing photographic record was also made in Ayer Hitam Forest Reserve in Johor by M. Silvius of Wetlands International on 26.xi.2010. Image 9. 5:2 males, RAD, 22.ix; 1 male, RAD, 23.ix; 1 male, CYC, 23.ix.

(xxi) Urothemis signata insignata (Selys, 1872) 7:1 male, RAD, 20.ix.

(xxii) Zyxomma petiolatum Rambur, 1842 - 4:1 female, RAD, 21.ix.

\section{DISCUSSION}

Although we had modest hopes of making interesting finds at Sungai Bebar, we were not expecting to make six new records for Peninsular Malaysia and mainland Asia in just five days of fieldwork. These discoveries demonstrate how poorly surveyed Odonata have been in low $\mathrm{pH}$ swamp forest habitats in mainland Southeast Asia; more discoveries can be expected with further collecting effort.

Many parts of the peat swamp habitat around Sungai Bebar are only accessible by small boat. The riverbanks and shallow parts of the river have an extensive growth of Pandanus, which at some points completely clogs the waterway. The Jakun (indigenous people living around Sungai Bebar) normally burn the overgrown Pandanus during the dry season to clear a passage. The clear, low $\mathrm{pH}$ waters and vegetation structure of the river appear to provide an ideal habitat for a number of Odonata: Ictinogomphus acutus, I. decoratus, Macromia cincta, Chalybeothemis fluviatilis, Elattoneura aurantica and Pseudagrion williamsoni were abundant along the entire section of the river sampled.

Despite the new records made at Sungai Bebar, there were also some surprising absences from our sample. In Borneo, species of the coenagrionoid genera-Mortonagrion and Teinobasis-are almost invariably found in such habitats. Members of these genera, especially the small Mortonagrion, are typically inconspicuous, but the authors have considerable 
experience of collecting Odonata, and were looking out for these genera. However, the three species currently placed in Mortonagrion and known from Peninsular Malaysia-M. aborense (Laidlaw 1914), M. arthuri Fraser, 1942 and M. falcatum Lieftinck, 1934 - are not necessarily swamp forest species (see Dow 2011 for a discussion of $M$. arthuri). Four species of Teinobasis are known from Peninsular Malaysia (Dow 2010): $T$. cryptica Dow, 2010, T. kirbyi Laidlaw, 1902, T. rajah Laidlaw, 1912, T. ruficollis (Selys, 1877); of these all except $T$. kirbyi would be expected in the habitats at Sungai Bebar, and are likely to be found there with further collecting.

In other respects the odonate fauna of Sungai Bebar is similar to that of low $\mathrm{pH}$ swamp forest in Borneo: rich in coengrionoids, especially Amphicnemis, and libellulids, poorer in numbers of species from other families, but including a number of specialist species from some of these families. The protoneurid genus Elattoneura is well represented at Sungai Bebar, with three species. All the Amphicnemis and Elattoneura (except $E$. analis) species of Peninsular Malaysia are inhabitants of alluvial swamp or peat swamp forest. All of the Amphicnemis (except A. ecornuta Selys, 1889 ) and Elattoneura (again except $E$. analis) species that have so far been recorded for Peninsular Malaysia were found at Sungai Bebar. This suggests that the Sungai Bebar area still has enough high quality habitat to sustain a high diversity of specialist peat swamp forest species. Several gomphids were collected on the Sungai Bebar, and more can be expected there, and on smaller streams in the swamp forest. Of the Gomphidae so far recorded at Sungai Bebar, Ictinogomphus acutus appears to be a specialist of low pH habitats (see Dow \& Unggang 2010). Additional members of the Corduliidae, for instance Hemicordulia tenera Lieftinck, 1930, are to be expected. Swamp forest in SE Asia is sometimes rich in members of the Aeshnidae, in particular species of Gynacantha and Heliaeschna. However, the Aeshnidae are typically difficult to collect so that their diversity in an area is normally only revealed over longer sampling periods; more than the single species recorded to-date must occur in the Sungai Bebar area.

\section{REFERENCES}

Choong, C.Y. (2009). A preliminary survey of Odonata fauna of Panti Forest Reserve, pp. 223-228. In. Seiri Kepelbagaian Biologi Hutan 11: Hutan Simpan Panti, Johor - Pengurusan Hutan, Persekitaran Fizikal dan Kepelbagaian Biologi. Jabatan Perhutanan Semenanjung Malaysia.

Choong, C.Y., A.G. Orr \& R.A. Dow (2008). Checklist of dragonflies of UKM Campus. including Bangi Forest Reserve, Bangi, Selangor, Malaysia. Echo 5: 4-5.

Dow, R.A. (2010). A review of the Teinobasis of Sundaland, with the description of Teinobasis cryptica sp. nov. from Malaysia (Odonata: Coenagrionidae). International Journal of Odonatology 13(2): 205-230, pl. II excl.

Dow, R.A. (2011). Mortonagrion indraneil spec. nov. from Borneo, and a redescription of $M$. arthuri Fraser (Odonata: Zygoptera: Coenagrionidae). Zootaxa 3093: 35-46.

Dow, R.A., C.Y. Choong \& Y.F. Ng (2010). A review of the genus Amphicnmemis in Peninsular Malaysia and Singapore, with descriptions of two new species (Odonata: Zygoptera: Coenagrionidae). Zootaxa 2605: 45-55.

Dow, R.A., C.Y. Choong \& A.G. Orr (2007). Two new species of Chalybeothemis from Malaysia, with a redefinition of the genus (Odonata: Libellulidae). International Journal of Odonatology 10(2): 171-184.

Dow, R.A. \& J. Unggang (2010). The Odonata of Binyo Penyilam, a unique tropical wetland area in Bintulu Division, Sarawak, Malaysia. Journal of Threatened Taxa 2(13): 1349-1358.

Hämäläinen, M. (2000). Ten species added to the list of Peninsular Malaysian Odonata. Notulae Odonatologicae 5(5): 53-55.

Kalkman, V.J. (2004). From cool hill resorts to humid rainforest: an odonatological trip to Peninsular Malaysia (July 2002). Echo 1, in Agrion 8(2): 26-28.

Lieftinck, M.A. (1940). Descriptions and records of South-east Asiatic Odonata (II). Treubia 17: 337-390.

Lieftinck, M.A. (1954). Handlist of Malaysian Odonata. A catalogue of the dragonflies of the Malay Peninsula, Sumatra, Java and Borneo, including the adjacent small islands. Treubia (Suppl.) 22: i-xiii+1-202.

Norma-Rashid, Y., A. Mohd-Sofian \& M. Zakaria-Ismail (2001). Diversity and distribution of Odonata (dragonflies and damselflies) in the freshwater swamp lake Tasek Bera, Malaysia. Hydrobiologica 459: 135-146.

Orr, A.G. (2001). An annotated checklist of the Odonata of Brunei with ecological notes and descriptions of hitherto unknown males and larvae. International Journal of Odonatology 4: 167-220.

Orr, A.G. (2003). Dragonflies of Borneo. Natural History Publications (Borneo), Kota Kinabalu, $\mathrm{x}+195 \mathrm{pp}$. 
Orr, A.G. (2005). Dragonflies of Peninsular Malaysia and Singapore. Natural History Publications (Borneo), Kota Kinabalu, vi+127pp.

Tang, H.B., L.K. Wang \& M. Hämäläinen (2010). A photographic guide to the Dragonflies of Singapore. Raffles Museum of Biodiversity Research, 5+223pp.

UNDP (2006). Malaysia's peat swamp forests. Conservation and sustainable use. United Nations Development Programme (UNDP), Malaysia, iv +33 pp. Available from http://202.187.94.201/Malaysias-peat-swamp-forests-conservation-andsustainable-use. Accessed 13 January 2010.
Author Details: RoRY A. Dow is a research associate at NCB Naturalis, Leiden, the Netherlands. His research interests are in the faunistics and taxonomy of Asian Odonata. $\mathrm{He}$ has extensive experience of working in southeast Asia, especially in Malaysia.

YONG Foo NG is an insect taxonomist in the School of Environmental and Natural Resource Sciences, Universiti Kebangsaan Malaysia (UKM) and a member of the Centre for Insect Systematics, UKM. His research is focused on Asian Odonata and Thysanoptera. $\mathrm{He}$ collaborates with researchers from CSIRO, Entomology Department, Canberra, Australia and NCB Naturalis, Leiden, Netherlands

CHEE Yen CHOONG is a lecturer of School of Environmental and Natural Resource Sciences, Universiti Kebangsaan Malaysia (UKM). $\mathrm{He}$ is an associate member of the Centre for Insect Systematics, UKM, and has a profound interest in the dragonflies and damselflies of Peninsular Malaysia.

Author Contribution: RAD identification of, and information on, the Odonata collected, collection of specimens. YFN information on the area sampled, and on peat swamp forest in Peninsular Malaysia; organization of the sampling trip. CYC identification of, and information on, the Odonata collected, collection of specimens, photography. 